\title{
Zagospodarowanie terenów poprzemysłowych na przykładzie Zakładów Radiowych „Diora” w Dzierżoniowie
}

\section{Re-Use of Post-Industrial Sites Based on the Example of 'Diora' in Dzierzioniów}

\begin{abstract}
Streszczenie: Zakłady Radiowe „Diora” były największym przedsiębiorstwem w historii Dzierżoniowa, a ich marka znana była zarówno w Polsce, jak i za granicą. Dzięki temu stały się one główną determinantą rozwoju, a także pewnym symbolem i wizytówką miasta. Po upadku „Diory” pojawił się problem zagospodarowania budynków zakładu, które zajmowały znaczny obszar w centralnej części Dzierżoniowa i stopniowo ulegały degradacji. Ostatecznie władze lokalne podjęły kontrowersyjną decyzję o likwidacji pozostałości fabryki oraz zmianie funkcji i charakteru tego obszaru. Na miejscu głównej hali „Diory” powstał największy w mieście hipermarket „Kaufland”, a obok rozwinęła się prężnie działająca strefa usługowa. Celem artykułu jest ukazanie procesu zmian funkcjonalno-przestrzennych na obszarach poprzemysłowych „Diory”, zmierzających do ponownego zagospodarowania i rewitalizacji tego miejsca. Zostanie omówiony schemat działania władz lokalnych oraz poszczególne etapy kształtowania się nowej strefy usługowej wraz z inwentaryzacją podmiotów gospodarczych tam powstałych. Przykład zagospodarowania „Diory” przedstawiony zostanie w kontekście dobrych praktyk, co może posłużyć jako wzór postępowania dla innych miast monofunkcyjnych, które borykają się z podobnymi problemami.
\end{abstract}

\begin{abstract}
Diora Factory was the largest company in the history of Dzierżoniów and its brand was well-known throughout Poland. Therefore Diora was a determinant of development, as well as the symbol of the town. After the liquidation of Diora, there appeared a problem of revitalisation of postindustrial sites occupying significant area in the centre of the town. Finally, local authorities decided to demolish the bulk of Diora's buildings and change the function and nature of the area. On the site of the main building of Diora was formed a large hypermarket 'Kaufland' with many additional services. Other buildings next to the hypermarket were transformed to service zone, where many economic operators located their companies. The aim of this study was to show the process of change aimed at the revitalisation of this place. This article contains: analysis of local authorities' actions aimed at the revitalisation of this place, principles of creating a new service zone and identification of economic operators in this zone. These changes have resulted in converting useless post-industrial areas in the rapidly developing service zone. Revitalisation of Diora Factory can be used as an example of good practice for other monofunctional cities, which have the same problems.
\end{abstract}

Słowa kluczowe: miasto monofunkcyjne; rewitalizacja; strefa usługowa; tereny poprzemysłowe Keywords: monofunctional city; post-industrial area; revitalisation; service zone 
Otrzymano: 7 września 2017

Received: 7 September 2017

Zaakceptowano: 4 lipca 2018

Accepted: 4 July 2018

\section{Sugerowana cytacja / Suggested citation:}

Jurkowski, W. (2018). Zagospodarowanie terenów poprzemysłowych na przykładzie Zakładów Radiowych „Diora” w Dzierżoniowie. Prace Komisji Geografii Przemysłu Polskiego Towarzystwa Geograficznego, 32(3),

174-185. https://doi.org/10.24917/20801653.323.11

\section{WSTĘP}

Przekształcenia gospodarcze z początku lat dziewięćdziesiątych XX wieku spowodowały, że wiele niegdyś sprawnie działających zakładów przemysłowych nie odnalazło się w nowych realiach gospodarki rynkowej. Polska wkroczyła w etap przebudowy sektorowej struktury gospodarczej, co wiązało się z recesją przemysłu i dynamicznego rozwoju sektora usługowego (Rachwał, 2010). Kryzys i upadek wielu przedsiębiorstw z tego okresu odcisnął swoje piętno w przestrzeni, pozostawiając w miastach rozległe tereny poprzemysłowe (Domański, 2002).

Pojęcie terenu poprzemysłowego jest niejednoznaczne i nie doczekało się jednej, obowiązującej definicji w literaturze przedmiotu. Takie obszary są elementem szeroko rozumianych przestrzeni zdegradowanych $\mathrm{w}$ mieście, określanych $\mathrm{w}$ literaturze zagranicznej jako brownfields (Domanowska, 2010). Według „Programu rządowego dla terenów poprzemysłowych” (2004) są one częściowo lub całkowicie nieużytkowane, a pierwotnie były przeznaczone na działalność gospodarczą lub pełniły funkcje pomocnicze w obrębie danego zakładu. Dodatkowo w zakres terenów poprzemysłowych można włączyć tzw. strefy oddziaływania przemysłu, np. składowiska odpadów, skażone wody i gleby (Domański, 2000). Zagospodarowanie terenów poprzemysłowych stanowi obecnie jedno z poważniejszych wyzwań polityki przestrzennej polskich miast. Po akcesji do Unii Europejskiej zachętą do tego typu działań stały się unijne środki finansowe oraz możliwość udziału w międzynarodowych projektach rewitalizacji (np. projekt COBRAMAN) (Muszyńska-Jeleszyńska, Jasińska, 2013). Zagospodarowanie terenów poprzemysłowych ma prowadzić w efekcie do rewitalizacji danego miejsca, czyli szeroko pojętych zmian na gruncie przestrzennym, gospodarczym i społecznym, których celem jest wyjście z sytuacji kryzysowej i zrównoważony rozwój (Behr, Billert, Kröning, Muzioł-Węcławowicz, 2003; Lorens, 2010).

W literaturze można wyróżnić wiele modeli rewitalizacji terenów poprzemysłowych (Baborska-Narożny, 2012; Kobylańska, Gawor, 2017). Obejmują one zarówno przywrócenie działalności przemysłowej, jak i adaptację obiektów do nowej funkcji, a także ich likwidację, zmianę funkcji i charakteru miejsca. Działania rewitalizacyjne można podzielić również na implementacyjne, kiedy decyzje podejmowane są bez zainteresowania społecznego, i integracyjne, włączające społeczność lokalną w procesy decyzyjne (Strzelecka, 2011). W ostatnich czasach zwykle najwięcej uwagi poświęca się ponownemu wykorzystaniu obiektów przemysłowych do funkcji handlowo-rekreacyjnych przy zachowaniu charakteru i wyglądu danego miejsca. Tego typu działania stawiane są za wzór, ponieważ oprócz przywrócenia aktywności w obrębie zdegradowanych obszarów odrestaurowane zostają dawne obiekty przemysłowe o wysokiej wartości architektonicznej i sentymentalnej, stając się atrakcją turystyczną samą w sobie. Przykładem 
tego typu działań jest choćby stworzenie Centrum Handlowego Manufaktura w Łodzi w miejsce fabryki I.K Poznańskiego (Świerczewska-Pietras, 2009) czy też przekształcenie browarów Huggera na Centrum Handlu, Sztuki i Kultury Stary Browar w Poznaniu (Tölle, 2007). Ze względu na ograniczone fundusze bądź problemy natury administracyjno-prawnej (np. własność obiektów) nie we wszystkich przypadkach tego typu działania są możliwe do realizacji. Dlatego też często nie podejmuje się żadnych decyzji, a tereny ulegają całkowitej degradacji i stwarzają pole do rozwoju patologii społecznych.

Niniejsza praca wpisuje się w kontekst badań nad zagospodarowaniem terenów poprzemysłowych czy też w bardziej ogólnym ujęciu - ich rewitalizacją. Jest to uzupełnienie dotychczasowej wiedzy o opis działań, zwykle pomijanych bądź pobieżnie charakteryzowanych w literaturze przedmiotu. Podstawą tych działań jest całkowita likwidacja pierwotnego obiektu i zmiana funkcji bez nawiązania do industrialnej przeszłości danego miejsca. Jest to działanie dość radykalne, wzbudzające wiele kontrowersji społecznych, jednak w przypadku braku możliwości innych rozwiązań wydaje się najbardziej racjonalne. Artykuł ma charakter studium przypadku, a głównym jego celem jest charakterystyka zmian funkcjonalno-przestrzennych na obszarach poprzemysłowych „Diory”, zmierzających do ponownego zagospodarowania i rewitalizacji tego miejsca. Zmiany te spowodowały przekształcenie nieużytecznych już terenów przemysłowych w sprawnie funkcjonującą strefę usługową o dominacji funkcji handlowej, za sprawą największego w mieście hipermarketu Kaufland. Działania rewitalizacyjne na terenach „Diory” mogą stanowić pewien wzór postępowania dla innych miast o dawnym, monofunkcyjnym charakterze, w których nie ma możliwości zastosowania innego typu rozwiązań.

W ramach realizacji celu głównego pracy można wyróżnić dwa cele pomocnicze. Pierwszy z nich to analiza rozwoju i regresu przedsiębiorstwa od 1945 roku do czasów obecnych, drugi zaś to identyfikacja poszczególnych etapów przekształceń terenów poprzemysłowych „Diory” w strefę usługową. W pierwszej części artykułu autor posługiwał się przede wszystkim źródłami wtórnymi, głównie publikacjami o charakterze historycznym. Druga część ma charakter empiryczny, wykorzystane zostały źródła pochodzące z inwentaryzacji terenowej, na bazie których dokonano opisu statystycznego obecnej struktury gospodarczej terenów poprzemysłowych „Diory”. Niestety, dużym problemem w badaniach przedsiębiorstw przemysłowych w Polsce jest utrudniony dostęp do baz danych, co znacznie ogranicza możliwości badawcze i zawęża spektrum podejmowanych wątków. Zwykle najłatwiej jest pozyskać jedynie te dane, które dotyczą przedsiębiorstw notowanych na giełdzie papierów wartościowych i które muszą być obligatoryjnie upubliczniane (Rachwał, 2008).

\section{RYS HISTORYCZNY „DIORY”}

Zakłady Radiowe „Diora” to pierwsza polska fabryka odbiorników radiowych po II wojnie światowej. Produkowany przez nią sprzęt od samego początku cieszył się wielkim uznaniem, zarówno w kraju, jak i za granicą, czego dowodem była produkcja dla takich firm, jak Thomson czy Brandt. W krótkim czasie „Diora” stała się jedną z najbardziej znanych firm elektronicznych i teletechnicznych w Polsce, a przez to wizytówką Dzierżoniowa.

Początki działalności „Diory” związane były z osobą Wilhelma Rotkiewicza, organizatora i pierwszego dyrektora firmy, nazywanego później pionierem polskiej 
radiotechniki. W 1945 roku Centralny Zarząd Przemysłu Elektrotechnicznego powierzył Rotkiewiczowi zadanie uruchomienia fabryki radioodbiorników w Świdnicy. Ostatecznie jednak lokalizację zmieniono na Dzierżoniów, ze względu na możliwość adaptacji budynków byłych zakładów radiotechnicznych, a także formowanie się już w pobliżu Wytwórni Lamp Radiowych (Dąbrowski, 1998). Przedsiębiorstwo rozpoczęło swoją działalność pod nazwą Państwowa Fabryka Odbiorników Radiowych (Dąbrowski, 1998). Rok później, pod kierownictwem Józefa Buczyłki, powstała również Szkoła Przemysłowa Radiotechniczna w Dzierżoniowie (obecnie Zespół Szkół nr 1), kształcąca przyszłych pracowników (Chabros, 2006). Do Dzierżoniowa przyjechali również fachowcy z Towarzystwa Elektrotechnicznego Elektrit funkcjonującego w Wilnie, które przed wojną było międzynarodową marką i jedynym polskim eksporterem odbiorników radiowych (Berezowski, 2011).

Pierwszym sprzętem produkowanym w „Diorze” był radioodbiornik Ludowy, którego produkcja opierała się na niemieckich schematach, wykorzystując dodatkowo podzespoły z tego kraju. Dwa lata po rozpoczęciu działalności zakupiono licencję odbiornika Aga, szwedzkiej firmy o tej samej nazwie, którą produkowano już w sposób taśmowy. Doświadczenia związane z produkcją Agi i odbiorników Ludowy zaowocowały stworzeniem własnego produktu, a zarazem pierwszego polskiego radioodbiornika, znanego jako Pionier (Ligarski, 2007). Był to pewien symbol polskiej myśli technicznej, który odegrał ogromną rolę w bezprzewodowej radiofonizacji kraju, a jego zaletami była prostota i przystępna cena (Strużak i in., 2009).

Od 1957 roku nazwa Państwowa Fabryka Odbiorników Radiowych zostaje przekształcona na Zakłady Radiowe „Diora” (Perlak, 2007). Do końca 1959 roku fabryka wyprodukowała około 2,5 mln odbiorników, a roczny wskaźnik produkcji wynosił 459572 sztuk (Dąbrowski, 1998). Sukces „Diory” przełożył się również na rozwój miasta, które w ciągu 15 lat po II wojnie światowej zwiększyło blisko dwukrotnie swoją liczbę ludności (1946 rok - 16 646, 1960 rok - 27 152) (GUS, 2017). W latach sześćdziesiątych firma rozpoczyna produkcję odbiorników telewizyjnych, z takimi modelami jak Aladyn, Tosca czy Szeherezada, a także innych urządzeń, jak radiotelefony górnicze, pehametry czy styczniki (Diora, 2016). Wprawdzie już w tym momencie przedsiębiorstwo stało się jednym z najbardziej znanych w swojej dziedzinie w Polsce, jednak największy rozkwit to lata siedemdziesiąte i osiemdziesiąte. Wtedy to Zakłady Radiowe „Diora” dołączyły do Zjednoczenia Przemysłu Elektronicznego i Elektrotechnicznego „UNITRA”, zrzeszającego najważniejsze firmy z branży, co pozwoliło na większy rozwój (Nowastowski, 2015). Jednym z przełomowych etapów była dla „Diory” produkcja pierwszych w Polsce odbiorników stereofonicznych, które wprowadziły nową jakość na rynku elektronicznym. Najpopularniejszymi odbiornikami tego typu były Amator Stereo, a także Elizabeth, produkowane we współpracy z japońską firmą Tokyo-Sanyo Electric Co., w których zastosowano innowacyjne jak na tamte czasy rozwiązania, m.in.: diody LED, układy scalone czy filtry ceramiczne. Po upowszechnieniu się stereofonii, „Diora” jako pierwsza wprowadza na rynek radioodbiorniki hi-fi, w tym słynną Meluzynę, do której dodano potem wzmacniacz kwadrofoniczny (Diora, 2016).

W latach największego rozkwitu fabryka zatrudniała blisko 7 tys. pracowników, będąc drugim co do wielkości zatrudnienia zakładem przemysłu elektronicznego w Polsce, ustępującym miejsca jedynie Naukowo-Produkcyjnemu Centrum Półprzewodników „Unitra-Cemi” z Warszawy (Hutnik, Pachniewicz, 1994). Dla porównania, w 2014 roku, przy zbliżonej liczbie ludności w mieście, „Podstrefa Dzierżoniów” (należąca do 
Wałbrzyskiej Specjalnej Strefy Ekonomicznej), gdzie skupiona jest większość dzierżoniowskich zakładów przemysłowych, zatrudniała zaledwie 2185 osób (Urząd Miasta w Dzierżoniowie, 2017).

Niestety, jak się później okazało, przełom lat osiemdziesiątych i dziewięćdziesiątych XX wieku to początek kryzysu „Diory”, czego dowodem był drastyczny spadek liczby zatrudnionych (ok. 90\%) (Rachwał, 2002). Na początku zakład został przekształcony w spółkę akcyjną Diora S.A., natomiast pod koniec lat dziewięćdziesiątych XX wieku ze spółki tej wyodrębniono kilka mniejszych spółek, takich jak Dionar, Diotech, Diora-serwis, Galwanizer, Diora Świdnica, a sama firma macierzysta ogłosiła upadłość. Właściwie już ten moment można uznać za upadek przedsiębiorstwa, jednak oficjalna likwidacja nastąpiła w 2006 roku, kiedy to sąd gospodarczy wykreślił firmę Diora S.A. z rejestru podmiotów gospodarczych (Urząd Miasta w Dzierżoniowie, 2017). Za główne powody upadku Diory podaje się otwarcie rynku i konkurencję ze strony zachodnich firm, których sprzęt był wprawdzie mniej solidny i trwały, ale prezentował się lepiej od strony wizualnej, był reklamowany i często sprzedawany po promocyjnych cenach. Dodatkowo ocenia się, że duży wpływ na tę sytuację miało złe zarządzanie i nieefektywne decyzje, szczególnie w ostatniej fazie działalności, które ostatecznie pogrążyły firmę.

\section{ZAGOSPODAROWANIE TERENÓW „DIORY”}

Upadek „Diory” wiązał się z zapaścią gospodarczą całego Dzierżoniowa, który miał charakter miasta monofunkcyjnego. Wzrosło bezrobocie, nasiliły się migracje zarobkowe, pojawiły się także problemy społeczne. W kontekście przestrzennym natomiast należało poradzić sobie z zagospodarowaniem terenów oraz budynków należących do fabryki, które zajmowały znaczny obszar centralnej części miasta. Tereny „Diory” stały się symbolem upadku dzierżoniowskiego przemysłu, a także końca pewnego rozdziału w historii miasta. Wydawało się, że obszar ten pozostanie na zawsze reliktem dawnej epoki i będzie stopniowo niszczeć oraz odstraszać swoim wyglądem, jak to często bywa po upadku głównego zakładu przemysłowego w mieście. W pewnym momencie jednak władze miasta podjęły odważną decyzję. Na podstawie uchwały nr XXXI/213/04 Rady Miejskiej Dzierżoniowa (Uchwała nr XXXI/213/04..., 2004) postanowiono rewitalizować teren poprzemysłowy poprzez adaptację i rehabilitację obszaru oraz przystosowanie zabudowy do funkcji usługowo-produkcyjnych i handlowych, co w praktyce oznaczało całkowite wyburzenie większości budynków „Diory”. Dodatkowo przewidywano realizację wielkopowierzchniowego obiektu handlowego o powierzchni do 2 tys. $\mathrm{m}^{2}$ lub innego podobnego, a warunkiem tej inwestycji miała być budowa drogi dojazdowej do obiektu i parkingów oraz modernizacja skrzyżowań. Teren dawnych zakładów „Diora” stanowił bardzo dobrą lokalizację, bowiem znajdował się on w połowie drogi pomiędzy centrum a największymi osiedlami Dzierżoniowa, tuż przy dwóch głównych arteriach komunikacyjnych, dlatego też na pojawienie się inwestora nie trzeba było długo czekać. Ofertę złożyła sieć marketów Kaufland, która jednak chciała wybudować większy obiekt, zatem od razu wystąpiła do burmistrza z prośbą zmiany miejscowego planu zagospodarowania przestrzennego i zezwolenie na budowę obiektu o powierzchni ok. 3,5 tys. $\mathrm{m}^{2}$. Wniosek rozpatrzono pozytywnie, burmistrz przygotował projekt uchwały, po czym w październiku 2009 roku Rada Miejska Dzierżoniowa przyjęła zmianę miejscowego planu zagospodarowania przestrzennego w uchwale nr XLIX/301/09 (Uchwała nr XLIX/301/09..., 2009), w której dopuszcza budowę obiektu przekraczającego 2 tys. m², 
Fot. 1. Hipermarket Kaufland w miejscu dawnych Zakładów Radiowych „Diora” w Dzierżoniowie kilka dni po otwarciu

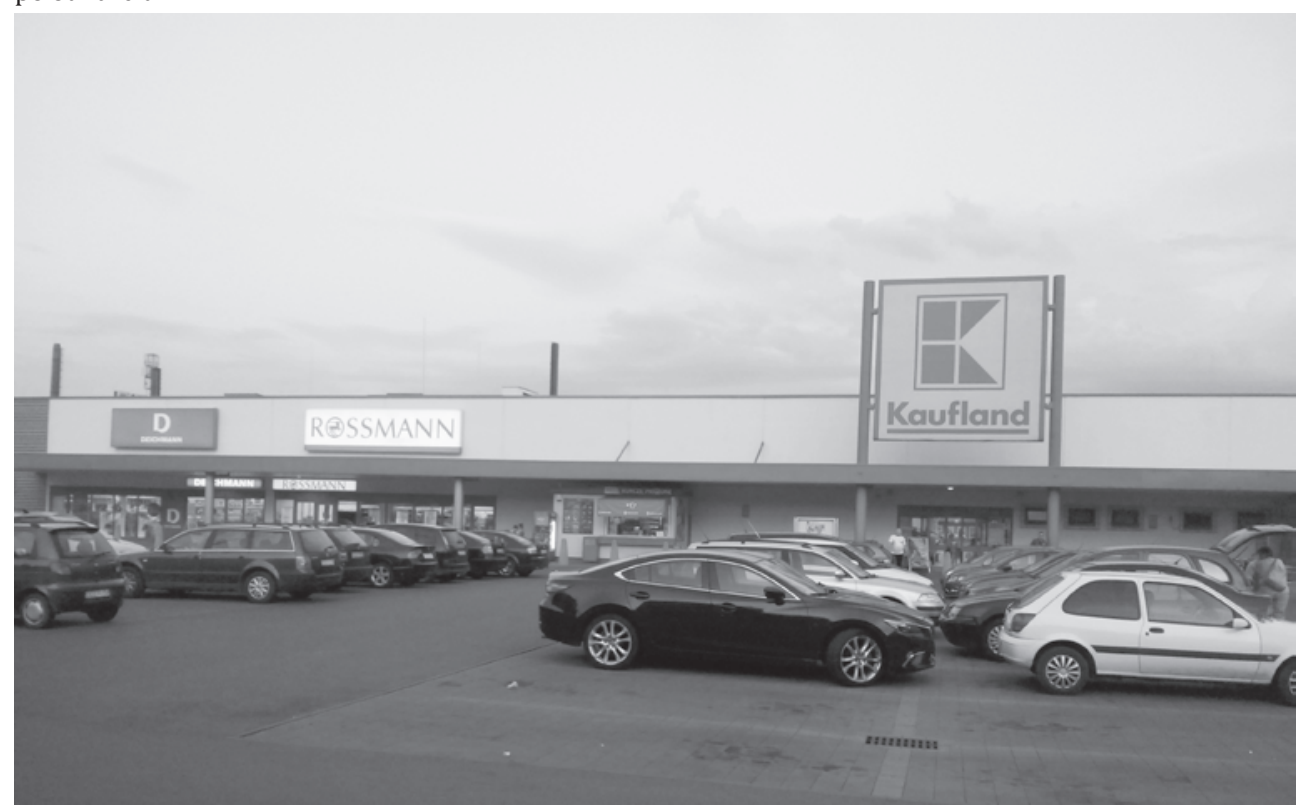

Źródło: fot. W. Jurkowski

przy zachowaniu warunku o zwiększeniu liczby miejsc parkingowych (Biuletyn Informacji Publicznej Miasta Dzierżoniów, 2017).

W 2012 roku hipermarket Kaufland został oficjalnie otwarty, stając się tym samym największym tego typu obiektem w Dzierżoniowie (fot. 1). Wraz z otwarciem obiektu handlowego pojawiła się również droga dojazdowa, nazwana ulicą Diorowską. Oprócz funkcji dojazdowej do marketu odgrywa ona niezwykle ważną rolę łącznika pomiędzy dwiema głównymi ulicami w Dzierżoniowie: Świdnicką i Piastowską. Warto podkreślić, że jest to dogodne połączenie z południowej części Dzierżoniowa w kierunku głównych osiedli mieszkaniowych, w tym największego - osiedla Różanego. Przed realizacją ulicy Diorowskiej, aby dostać się z części południowej w kierunku osiedli, na wysokości „Diory” trzeba było jechać okrężną trasą, nadrabiając około 1,2 km i pokonując dwa oblegane skrzyżowania, co dodatkowo intensyfikowało problemy komunikacyjne. Warto podkreślić, że tereny dawnej „Diory” wraz z przyległymi zakładami tworzyły pewien zamknięty obszar przemysłowy, niedostępny dla mieszkańców. Tym samym stanowiły sztuczną barierę w centralnej części miasta, która uniemożliwiała komunikację pomiędzy dwiema najważniejszymi ulicami w Dzierżoniowie. Dlatego też nowo powstała droga była doskonałą inwestycją w kontekście zwiększenia płynności ruchu, a także poprawy spójności w obrębie miasta.

Hipermarket Kaufland jako największy tego typu obiekt w mieście od razu zaczął przyciągać tłumy klientów. W samym obiekcie w krótkim czasie powstało wiele punktów usługowych, które dodatkowo zwiększały dobowe przepływy osób, co z kolei podnosiło atrakcyjność inwestycyjną tego miejsca. Okazało się, że tereny dawnych zakładów „Diora”, które były symbolem upadku przemysłu, stały się idealnym miejscem dla lokalizacji podmiotów gospodarczych. Potwierdziło się, że działania rewitalizacyjne 
oddziałują na otoczenie, bowiem inwestycja docelowa stała się impulsem dla kolejnych, co w efekcie przełożyło się na rozwój całego obszaru.

\section{PoWSTANIE NOWEJ STREFY USŁUGOWEJ}

W celu analizy struktury podmiotów zlokalizowanych na terenach poprzemysłowych „Diory” dokonano inwentaryzacji terenowej. Przeprowadzona została w sierpniu 2017 roku i pozwoliła zidentyfikować 59 podmiotów gospodarczych. Podczas inwentaryzacji brano pod uwagę tylko te podmioty, które posiadały szyld z nazwą spółki widoczny z zewnątrz budynku.

Można wyróżnić trzy charakterystyczne obszary koncentracji pomiotów gospodarczych: pierwszy wewnątrz obiektu Kaufland, drugi wzdłuż ulicy Diorowskiej (wschodnia strona) i trzeci w obrębie budynków w północnej części przy ulicy Piastowskiej (ryc. 1). Wśród zinwentaryzowanych przedsiębiorstw blisko połowa zajmowała się handlem i naprawą (sekcja G według klasyfikacji PKD 2007) (ryc. 1). Najczęściej były to drobne punkty usługowe, jak piekarnia, sklep mięsny, sklep obuwniczy czy apteka, w obrębie kompleksu Kaufland. Jest to obecnie cecha charakterystyczna hipermarketów, które udostępniają część obiektu (najczęściej przy wejściu) dla innych podmiotów. Zwiększa to zakres oferowanych towarów, a przez to możliwości zakupowe w całym kompleksie, co przynosi korzyści zarówno hipermarketowi, jak i drobnym przedsiębiorcom. Drugim ważnym ogniwem jest przetwórstwo przemysłowe (blisko

Ryc. 1. Podmioty gospodarcze według sekcji PKD 2007 na terenach poprzemysłowych „Diory” w Dzierżoniowie w 2017 rok.

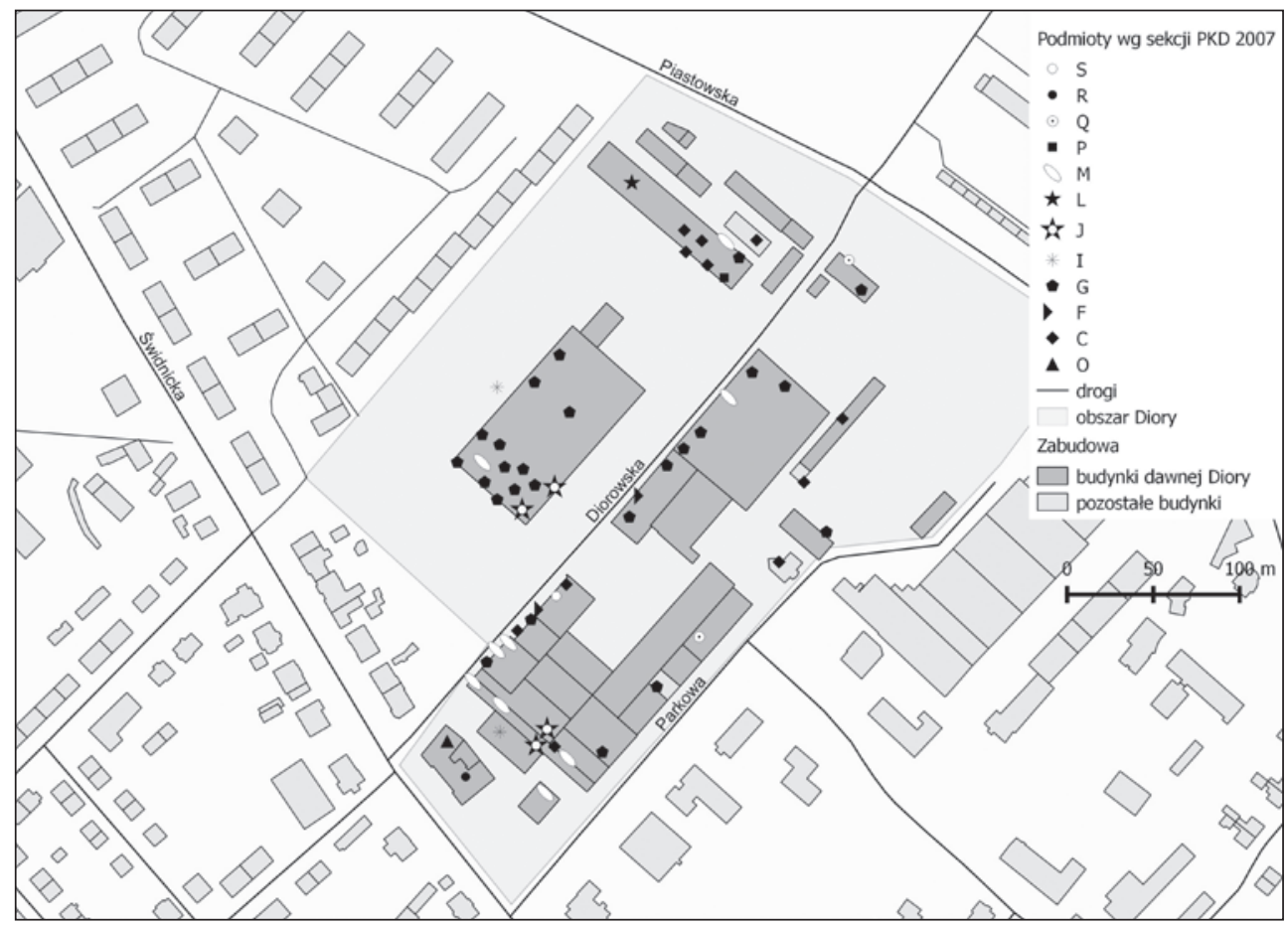

Źródło: opracowanie własne 
Ryc. 2. Struktura podmiotów zlokalizowanych na obszarze dawnych zakładów „Diora” w Dzierżoniowie w 2017 roku

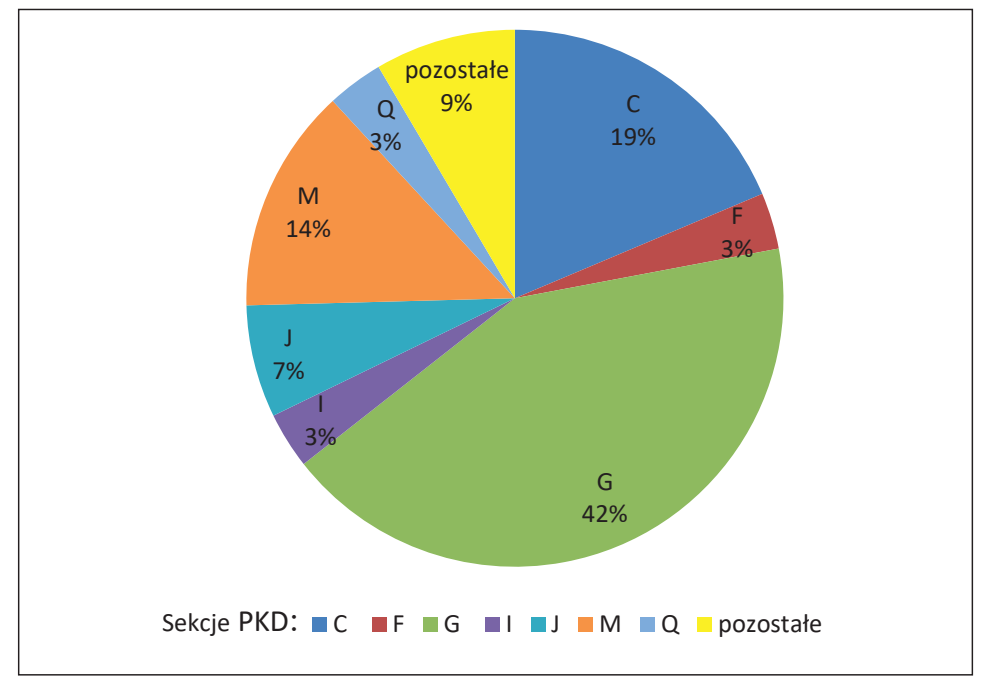

Źródło: opracowanie własne

1/5 podmiotów) - w Kauflandzie były to przedsiębiorstwa zajmujące się zarówno przemysłem skórzanym czy tekstylnym, jak i galwanicznym. Podmioty te zostały zlokalizowane głównie w dawnych budynkach „Diory” zaadaptowanych na potrzeby usług. $14 \%$ podmiotów sklasyfikowano do sekcji M, czyli jednej z usług otoczenia biznesu, tzw. działalności profesjonalnej, która reprezentowana była najczęściej przez kancelarie prawne i biura rachunkowe, rozmieszczone stosunkowo równomiernie w obrębie całego obszaru. Udział pozostałych sekcji ograniczał się co najwyżej do kilku procent. Były to często pojedyncze podmioty bez charakterystycznych cech lokalizacyjnych.

Wprawdzie struktura podmiotów nie nawiązuje wyraźnie do specjalizacji „Diory”, na której miejscu powstawały, jednak jest kilka podmiotów odwołujących się do tradycji przemysłowych tego miejsca. Jednym z głównych przedsiębiorstw przemysłowych w tej strefie jest Galwanizer, wyodrębniony jako jedna ze spółek „Diory” pod koniec lat dziewięćdziesiątych XX wieku, zajmujący się obecnie galwanizacją i cynkowaniem tworzyw. Pozostał też Diotech zajmujący się produkcją bądź obróbką metali, konstruowaniem oraz produkcją urządzeń elektronicznych.

Jak się okazało, budowa obiektu handlowego „Kaufland” była początkiem kolejnych inwestycji, które napędzały rozwój tego miejsca. Obecnie tereny dawnych zakładów „Diora” zaczynają pełnić funkcję śródmiejskiego centrum usługowego Dzierżoniowa. Dodatkowo znajduje się tam jeszcze wiele niezagospodarowanych obiektów, które stanowią potencjał dla lokalizacji kolejnych podmiotów. Istotne jest, że proces zagospodarowania terenów dawnych zakładów „Diora” przebiegał według określonego schematu (ryc. 3). Kluczowym elementem w procesie rewitalizacji była odważna decyzja, której często brakuje przy tego typu problemach. W tym przypadku była to decyzja o przeznaczeniu terenu na obszar rozwoju usług z możliwością budowy obiektu wielkopowierzchniowego. Bez wątpienia była to decyzja niełatwa, budząca kontrowersje, szczególnie ze względu na związek emocjonalny mieszkańców miasta z „Diorą”. Niemniej jednak określona decyzja i jasno zdefiniowane przeznaczenie tego obszaru 
Ryc. 3. Schemat działań rewitalizacyjnych na obszarach dawnej „Diory” w Dzierżoniowie w 2017 roku

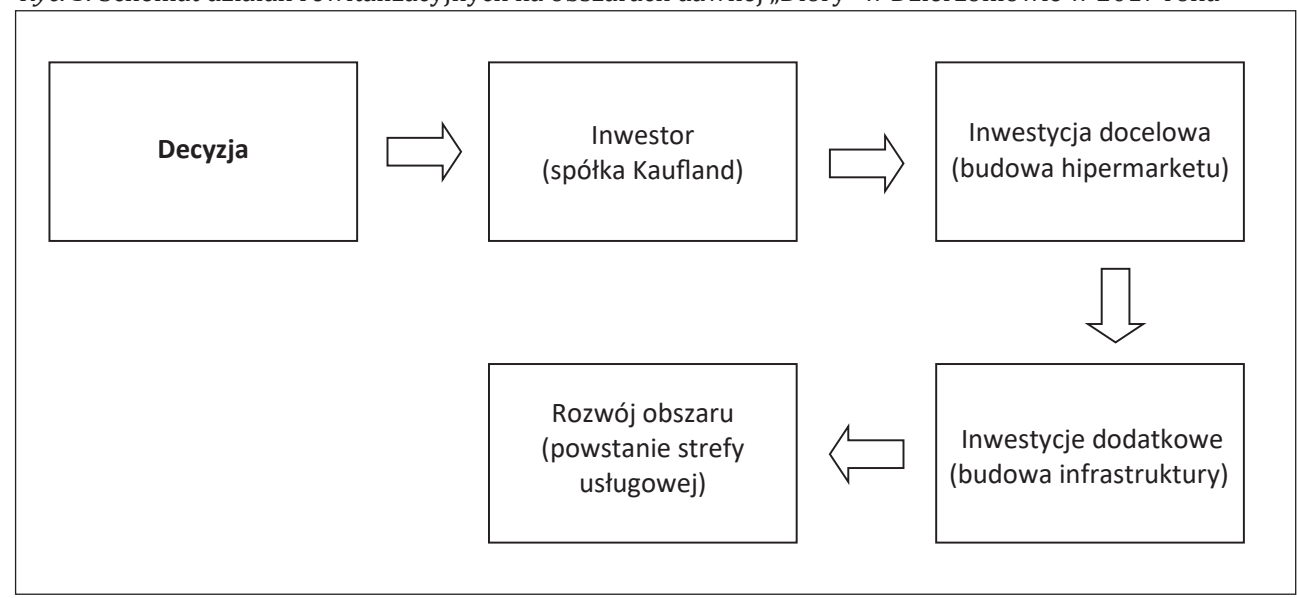

Źródło: opracowanie własne

Fot. 2. Tablice informujące o możliwościach inwestycyjnych przy ulicy Diorowskiej w obrębie terenów poprzemysłowych dawnej „Diory”

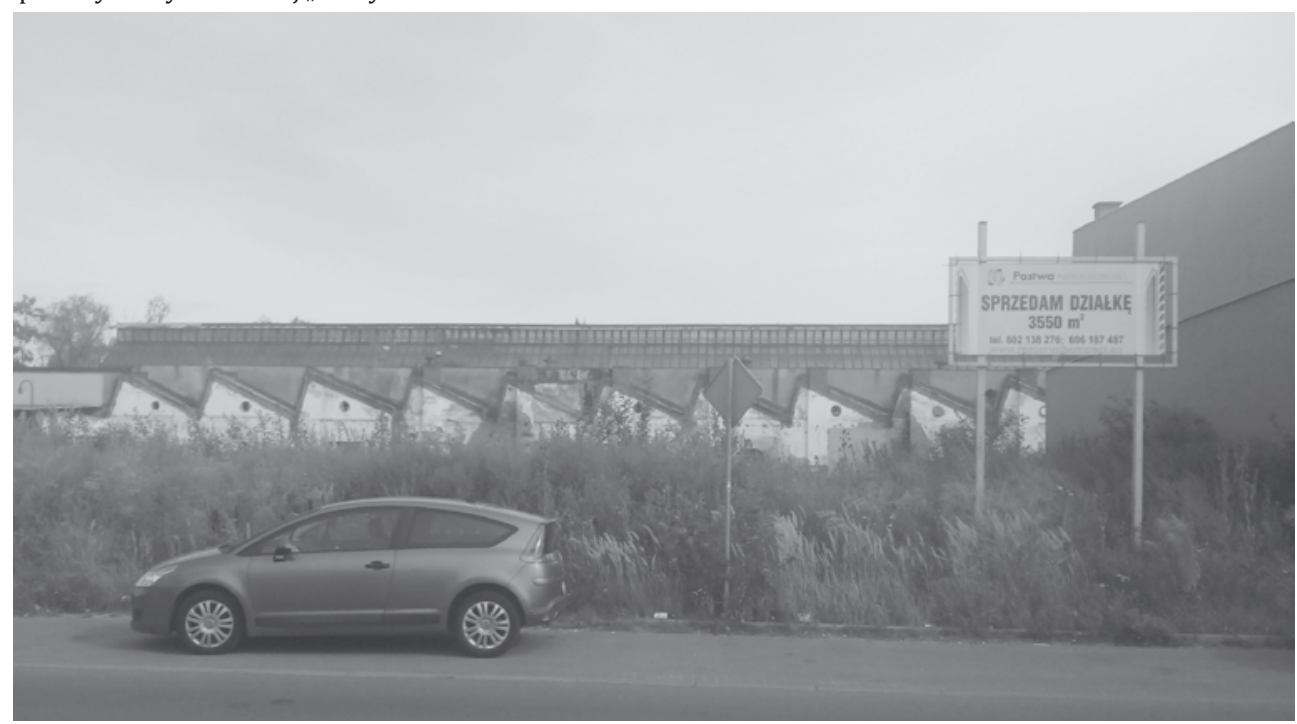

Źródło: fot. W. Jurkowski

spowodowało zainteresowanie inwestora, który zobowiązał do realizacji tzw. inwestycji docelowej, czyli budowy obiektu Kaufland. Inwestycja ta z kolei przyczyniła się do zwiększenia atrakcyjności inwestycyjnej tego obszaru, co pozwoliło na realizację wielu inwestycji dodatkowych, które są zawsze pochodną tej głównej i które w efekcie prowadzą do rozwoju obszaru. Inwestycje te były realizowane zarówno przez sieć Kaufland (np. budowa drogi czy parkingów), jak i przez kolejne podmioty, które lokalizowały tu swoją działalność. Powstał swoisty zespół naczyń połączonych gdzie jeden element staje się czynnikiem sprawczym następnego (por. Twardzik, 2016). Widoczne jest tutaj nawiązanie do tzw. efektu spill-over, czyli rozprzestrzeniania się pozytywnych 
zmian na obszary sąsiadujące. (Świerczewska-Pietras, 2009). Schemat można również uogólnić do trzech podstawowych kroków. Pierwszy z nich to etap wstępny, który obejmuje decyzję oraz pojawienie się inwestora, a także wzajemne rozmowy, następny etap to inwestycje, natomiast ostatni, silnie uzależniony od powodzenia wcześniejszych elementów, to etap korzyści, czyli rozwój danego obszaru.

Tereny poprzemysłowe „Diory” wciąż znajdują się w fazie rozwoju. Do pierwszego półrocza 2018 roku tuż obok hipermarketu Kaufland ma powstać kolejny park handlowy z dodatkowymi 250 miejscami parkingowymi (Scallier, 2017). Ponadto wzdłuż ulicy Diorowskiej zamieszczonych jest jeszcze kilka tablic informujących o możliwości kupna działki inwestycyjnej, przez co można prognozować, że liczba podmiotów będzie się systematycznie zwiększać (fot. 2). Dodatkowo planowane są inwestycje (Biedronka, McDolanald's) na terenach dawnego zakładu Defka, sąsiadujących z terenami poprzemysłowymi „Diory”, przez co cały ten obszar może stać się głównym centrum usługowym w mieście.

\section{PODSUMOWANIE I WNIOSKI}

Upadek zakładu przemysłowego o takim wielkim znaczeniu dla miasta jak „Diora” jest zawsze dużym wyzwaniem zarówno dla władz lokalnych, jak i dla mieszkańców. Oprócz problemów natury ekonomicznej i społecznej pojawia się również kontekst przestrzenny, związany z zagospodarowaniem terenów poprzemysłowych. Przykład „Diory” pokazał jednak, że likwidacja nawet tak ważnego przedsiębiorstwa nie musi oznaczać degradacji obszaru z nim związanego, a także stagnacji gospodarczej w mieście. Kluczowym elementem jest określona wizja, przełożona na konkretną decyzję, która z kolei była czynnikiem sprawczym kolejnych procesów. Sporządzenie miejscowego planu zagospodarowania przestrzennego, w którym przewidziano stworzenie strefy usługowej, spowodowało pojawienie się spółki, która zrealizowała inwestycję docelową, a ta z kolei pociągnęła za sobą kolejne, co w efekcie skutkowało rozwojem i rewitalizacją tego obszaru. Inwestycją docelową była budowa marketu Kaufland, dodatkowymi budowa parkingu i drogi dojazdowej łączącej dwie główne ulice w Dzierżoniowie. W krótkim czasie teren dawnej fabryki przekształcił się w sprawnie funkcjonującą strefę usługową, która pełni funkcję centrum miasta. Stefa ta przyciąga codziennie ogromną liczbę mieszkańców zarówno Dzierżoniowa, jak i okolicznych miejscowości, w tym ważnych miast: Bielawy, Pieszyc czy Piławy Górnej, dla których dzierżoniowski Kaufland jest najbliższym tego typu obiektem handlowym.

Decyzja o wyburzeniu obiektów dawnej „Diory” była działaniem odważnym i kontrowersyjnym. Dla wielu mieszkańców Dzierżoniowa zakłady te były przez wiele lat częścią ich życia, przez co miejsce to miało dużą wartość sentymentalną. Jednak w sytuacji braku możliwości adaptacji budynków do innej działalności gospodarczej i konieczności przeciwdziałania degradacji tych obszarów wydaje się, że decyzja władz lokalnych była krokiem naprzód i przyczyniła się do rewitalizacji tego miejsca. Warto zwrócić uwagę, że likwidacja „Diory” nie wiązała się z całkowitym zapomnieniem o industrialnej przeszłości miasta. Od kilku lat przy Miejskim Muzeum w Dzierżoniowie podziwiać można stałą ekspozycję poświęconą „Diorze”. Dodatkowo w ramach funkcjonującej akcji: „Ocalmy Diorę od zapomnienia” powstał szlak „Śladem kultowych radioodbiorników Diory”, w obrębie którego w ważnych miejscach pojawiają się figurki sprzętu „Diory”. 
Podsumowując, proces zagospodarowania terenów poprzemysłowych „Diory” można analizować w kontekście dobrych praktyk i stanowi on jedną z możliwości rewitalizacji dla innych monofunkcyjnych miast, które borykają się z problemem likwidacji głównego zakładu przemysłowego. Okazało się, że wystarcza zdecydowane, planowe działanie zmierzające do określonego celu, którego często brakuje w podobnym sytuacjach. Podkreśla to duże znaczenie planowania przestrzennego, które jest często podstawowym czynnikiem sprawczym pozytywnych zmian i może przyczynić się do poprawy funkcjonowania miasta. Udowodniono również, że rewitalizacja nie zawsze musi przebiegać według wzorcowego schematu propagowanego w innych miastach, ma ona wiele wariantów, które przy dobrej organizacji również mogą przynosić korzyści.

\section{Literatura \\ References}

Baborska-Narożny, M. (2012). Rewitalizacja terenów poprzemysłowych - modele przekształceń na wybranych przykładach. Czasopismo Techniczne Architektura, 109(3-A), 275-1279.

Behr, I., Billert, A., Kröning, W., Muzioł-Węcławowicz, A. (2003). Podręcznik rewitalizacji. Zasady, procedury i metody działania współczesnych procesów rewitalizacji. Warszawa.

Berezowski, H. (2011). Towarzystwo Radiotechniczne ELEKTRIT. Wilno 1925-1939, Warszawa.

Biuletyn Informacji Publicznej Miasta Dzierżoniów (2017, 21 sierpnia). Pozyskano z http:// www.bip.arch.um.dzierzoniow.pl

Chabros, E., (2006). Z dziejów Radiobudy 1946-2006. Dzierżoniów: Zespół Szkół nr 1 im. prof. Wilhelma Rotkiewicza w Dzierżoniowie.

Dąbrowski, S. (1998). Dzierżoniów. Zarys monografii miasta. Wrocław-Dzierżoniów: Wydawnictwo DTSK Silesia.

Diora (2016, 20 listopada). Pozyskano z http://www.diora.pl

Domanowska, M. (2010). Problematyka definiowania przestrzeni zdegradowanych. Problemy Rozwoju Miast, 2, 81-87.

Domański, B. (2000). Restrukturyzacja terenów poprzemysłowych w miastach. W: A. Geissler (red.). Rewitalizacja, rehabilitacja i restrukturyzacja - odnowa miast. Kraków: Instytut Gospodarki Przestrzennej i Komunalnej Oddział w Krakowie.

Domański, B. (2002). Przekształcenia terenów poprzemysłowych w województwach śląskim i małopolskim - prawidłowości i uwarunkowania. Prace Komisji Geografii Przemysłu Polskiego Towarzystwa Geograficznego, 3, 51-59.

GUS (2017, 15 sierpnia). Główny Urząd Statystyczny. Pozyskano z http://www.stat.gov.pl

Hutnik, M., Pachniewicz, T. (1994). Zarys historii polskiego przemysłu elektronicznego do 1985 r. Warszawa: SEP.

Kobylańska, M., Gawor, Ł. (2017). Problematyka przeobrażeń przestrzennych w procesach rewitalizacji terenów poprzemysłowych. Prace Komisji Geografii Przemysłu Polskiego Towarzystwa Geograficznego, 31(1), 68-80.

Ligarski, S. (2007). Zakłady Radiowe „Diora” w materiałach tajnej policji państwowej Polskiej Rzeczpospolitej Ludowej. W: S. Ligarski, T. Przerwa (red.). Dzierżoniów: wiek miniony: materiały pokonferencyjne. Wrocław: Oddział Instytutu Pamięci Narodowej-Komisji Ścigania Zbrodni przeciwko Narodowi Polskiemu.

Lorens, P. (2010). Rewitalizacja miast. Planowanie i realizacja. Gdańsk: Politechnika Gdańska.

Muszyńska-Jeleszyńska, D., Jasińska, M. (2013). Rewitalizacja terenów poprzemysłowych w Europie Środkowej - doświadczenia projektu COBRAMAN. Problemy Rozwoju Miast, 3, 95-104.

Nowastowski, J. (2015). Rozwój przemysłu elektrotechnicznego na tle przemian własnościowych w latach 1989-2011. Zeszyty Naukowe Wydziału Elektrotechniki i Automatyki Politechniki Gdańskiej, 43, 105-112.

Perlak, B. (2007). Początki przemysłu radiotechnicznego w Dzierżoniowie po II wojnie światowej na przykładzie Zakładów Radiowych „Diora”. W: S. Ligarski, T. Przerwa (red.). Dzierżoniów: 
wiek miniony: materiały pokonferencyjne. Wrocław: Oddział Instytutu Pamięci Narodowej Komisji Ścigania Zbrodni przeciwko Narodowi Polskiemu.

Program rządowy dla terenów poprzemysłowych (2004). Przyjęty przez Radę Ministrów w dniu 27 kwietnia 2004 roku. Pozyskano z https://docplayer.pl/542328-Program-rzadowy-dla-terenow-poprzemyslowych.html

Rachwał, T. (2002). Funkcjonowanie Krakowskich Zakładów Elektronicznych „Telpod” w świetle przemian w polskim przemyśle elektronicznym. Prace Komisji Geografii Przemysłu Polskiego Towarzystwa Geograficznego, 3, 167-180.

Rachwał, T. (2008). Problematyka badawcza funkcjonowania przedsiębiorstw przemysłowych. Prace Komisji Geografii Przemysłu Polskiego Towarzystwa Geograficznego, 11, 53-85.

Rachwał, T. (2010). Struktura przestrzenna i działowa przemysłu Polski na tle Unii Europejskiej w dwudziestolecie rozpoczęcia procesów transformacji systemowej. Prace Komisji Geografii Przemysłu Polskiego Towarzystwa Geograficznego, 16, 105-124.

Scallier (2017, 21 sierpnia). Obsługa Nieruchomości. Pozyskano z http://scallier.com

Strużak, R. Sobolewski, J., Grzybowski, M., Kałuski, M., Pietranik, M., Siczek, S., Tyrawa, P., Więcek, D. (2009). Pół wieku innowacji - prace Oddziału Instytutu Łączności we Wrocławiu. Telekomunikacja i Techniki Informacyjne, 3-4, 68-82.

Strzelecka, E. (2011). Rewitalizacja miast w kontekście zrównoważonego rozwoju. Budownictwo i Inżynieria Środowiska, 2, 661-668.

Świerczewska-Pietras, K. (2009). Rewitalizacja zamknięta jako przykład zagospodarowania poprzemysłowego obszaru Łodzi. Prace Komisji Geografii Przemysłu Polskiego Towarzystwa Geograficznego, 12, 173-182.

Tölle, A. (2007). Proces rewitalizacji miasta na przykładzie Poznania. Studia regionalne i lokalne, 2, 46-58.

Twardzik, M. (2016). Oddziaływanie galerii handlowych na śródmiejskie ulice handlowe Katowic. Acta Universitatis Lodziensis. Folia Geographica Socio-Oeconomica, 23, 67-85.

Uchwała nr XXXI/213/04 w sprawie uchwalenia miejscowego planu zagospodarowania przestrzennego obszaru w rejonie ul. Świdnickiej i Piastowskiej, z częścią terenu byłych Zakładów Radiowych Diora S.A. w Dzierżoniowie. Pozyskano z http://bip.um.dzierzoniow. pl/Article/id,319.html

Uchwała nr XLIX/301/09 zmieniająca uchwałę w sprawie uchwalenia miejscowego planu zagospodarowania przestrzennego obszaru w rejonie ul. Świdnickiej i Piastowskiego, z częścią terenu byłych Zakładów Radiowych „Diora” S.A. w Dzierżoniowie. Pozyskano z http://bip. um.dzierzoniow.pl/Article/id,958.html

Urząd Miasta w Dzierżoniowie (2017, 21 sierpnia). Pozyskano z http://www.dzierzoniow.pl

Wojciech Jurkowski, mgr, doktorant w Zakładzie Zagospodarowania Przestrzennego w Instytucie Geografii i Rozwoju Regionalnego na Uniwersytecie Wrocławskim. Zainteresowania badawcze to przede wszystkim transport zbiorowy i rozwój regionalny. Aktualnie realizowana jest rozprawa doktorska w zakresie relacji pomiędzy rozwojem zabudowy mieszkaniowej a systemem transportu kolejowego w strefach podmiejskich w kontekście problemów nieskoordynowanej suburbanizacji oraz kongestii w ruchu drogowym.

Wojciech Jurkowski, M.Sc, Ph.D. student at the Department of Spatial Management, Institute of Geography and Regional Development at the University of Wroclaw. His research interests focus on public transport and regional development. Currently, he is working on his $\mathrm{PhD}$ thesis concerning relation between housing development and railway system in suburban zones in the context of uncontrolled suburbanisation and road congestion problems.

\section{Adres/address:}

Uniwersytet Wrocławski

Wydział Nauk o Ziemi i Kształtowania Środowiska

Instytut Geografii i Rozwoju Regionalnego

Zakład Zagospodarowania Przestrzennego

ul. Kuźnicza 49/55, 50-138 Wrocław, Polska

e-mail: wojciech.jurkowski@uwr.edu.pl 